\title{
Biology of growth of Hoplias aff. malabaricus (Bloch, 1794) in a shallow pampean lake (Argentina)
}

\author{
Leandro Balboni, Dario César Colautti and Claudio Rafael Mariano Baigún
}

The trahira Hoplias aff. malabaricus is a top predator in pampean shallow lakes and is highly appreciated by recreational anglers and artisanal fishermen. Trahira growth from Yalca shallow lake was determined by lepidological analysis and age validated by marginal increment. When growth was fitted to the von Bertalanffy model, annual classes exhibited a bimodal pattern as a result of the presence of spring and summer annual cohorts associated with a three month spawning season, each period in turn showing different growth patterns. The trahira population-age structure at Yalca shallow lake showed a truncated profile with very low numbers of large adults and few individuals older than three to four years, thus producing an unbalanced length-structure population. Growth parameters and growth performance were similar to the corresponding parameters estimated for other shallow pampean lakes of the region, but strongly diverged from the data for those populations inhabiting subtropical and tropical environments. Such differences could be accounted for by dissimilarity in metabolic rates associated with thermal differences accompanying seasonal variability among latitudes as well as by the development of adaptive physiologic and demographic responses to cope with the high thermal amplitude and hydrologic instability observed in pampean lakes.

A traíra Hoplias aff. malabaricus é um predador de topo encontrado em lagoas rasas nos Pampas, muito apreciada nas pescas comerciais e esportivas. O crescimento da traíra no lago Yalca foi determinado através de análises lepidológicas, validadas a partir do incremento marginal. O crescimento foi ajustado ao modelo de von Bertalanffy, sendo que as classes de tamanho anuais apresentaram padrão bimodal devido à presença de coortes de primavera e verão, associadas à uma longa estação reprodutiva com diferentes padrões de crescimento. A estrutura etária da traíra do lago Yalca apresentou um perfil truncado, com um número pequeno de adultos de maior porte e poucos indivíduos com mais de três ou quatro anos, produzindo uma estrutura em tamanho desbalanceada. Os parâmetros e a performance de crescimento foram similares aos estimados para outros lagos rasos da região, mas fortemente divergentes de populações encontradas em ambientes tropicais e subtropicais. Tais diferenças podem estar relacionadas à diferentes taxas metabólicas associadas à variação térmica sazonal entre latitudes e ao desenvolvimento de respostas adaptativas fisiológicas e demográficas em resposta aos padrões termais altamente variáveis e instabilidade hidrológica observados nos lagos da região dos Pampas.

Key words: Age validation, Biological indices, Neotropical fish, Piscivorous fish, Trahira.

\section{Introduction}

The trahira, Hoplias aff. malabaricus, is a neotropical characiform fish of the Erythrinidae family with a geographical distribution ranging from Colombia to the temperate shallow lakes in Argentina, inhabiting the Atlantic slope basins within this broad latitudinal strip $\left(09^{\circ} \mathrm{N}\right.$ to $\left.37^{\circ} \mathrm{S}\right)$. The species inhabits lentic and lotic environments and is particularly adapted to shallow vegetated bodies of water because of its wide range of tolerance to dissolved oxygen, $\mathrm{pH}$, salinity, and temperature (Paiva, 1972; Rios et al., 2003; Saad et al., 2002). In Argentina, the trahira is distributed all along the Aymaran, Great Rivers,
Andean Cuyan, and Pampean ichthyogeographic provinces (Lopez et al., 2008) with its meridional distribution boundary in the southern portion of the pampean plains (Ringuelet et al., 1967; Lopez et al., 1994; Rosso, 2007).

The trahira is the largest-sized predator in shallow pampean lakes (Barla et al., 2003; Menni, 2004; Rosso, 2007). The species withstands artisanal and substantial recreational fishing (Lopez et al., 2001; Grosman et al., 2004), as is also true in other South American regions where this species is distributed (Oyakawa, 2003; Tordecilla-Petro et al., 2005). Despite the prominence of trahira's presence in pampean lakes, the little information gathered on growth parameters and age

Instituto Tecnológico de Chascomús, IIB-INTECH, 7130. Camino de Circunvalación Laguna, Km 6, 7130 Chascomús, Argentina. balboni@intech.gov.ar 
structure is conflicting (Ramirez, 1963; Domanico et al., 1993; Domanico, 1998; Grosman et al., 2004). These works also differed from studies performed in other Neotropical basins (Paiva, 1974; Moraes \& Barbola, 1995; Tordecilla-Petro et al., 2005), where maximum length and/or growth rate are clearly lower than the observed in pampean shallow lakes. Growth patterns have a strong influence on fish-population dynamics and thereby-along with the effect of environmental conditions, genetic characteristics, food availability, trophic interactions, and fishing practices strongly influence the ecology and management of such populations (Quist et al., 2003). Growth information becomes more relevant when gathered from populations that inhabit water bodies subjected to differing climatic and environmental circumstances, since divergent populations would be expected to adapt their life-history patterns in order to cope with local or regional environmental conditions. Temperature, for example, is likely one of the strongest selective forces exerted on many fish populations because that parameter influences spawning frequency, foraging patterns and survival (Philipp, 1992). Seasonal thermal regime across divergent latitudes furthermore can be reflected in different relationships to growth, among differing species (Modde \& Scalet, 1985; Conover, 1990; Galarowicz \& Hall, 2003; Quist et al., 2003).

In this study we attempted to analyze trahira-growth patterns and age structure in shallow Yalca Lake based on lepidological analysis and length and age composition. We also compared these results with the findings from previous studies performed in pampean lakes, as well as with other data obtained from different geographical areas in South America, with a focus on the potential influence of temperature on growth patterns.

\section{Material and Methods}

Yalca shallow lake is located in the lower Salado River basin (Fig. 1). The lake area is 1,150 hectares, but about $60 \%$ is covered by aquatic vegetation Typha latifolia (Linnaeus, 1753) and Scirpus giganteus (Kunth). The mean and maximum depths are around $1.40 \mathrm{~m}$ and $1.60 \mathrm{~m}$, respectively, with a wide littoral area containing gentle slopes (Frenguelli, 1956). During the study, lake transparency was very low (Secchi depth $=6 \mathrm{~cm} \pm 1.08 \mathrm{SD}$ ), mean conductivity was $0.46 \mathrm{uS} / \mathrm{cm}( \pm 0.13 \mathrm{SD})$, dissolved oxygen showed high levels $(7.52 \mathrm{mg} / 1 \pm 1.01 \mathrm{SD})$, and $\mathrm{pH}$ was neutral to alkaline $(7.89 \pm 0.79)$. As with other shallow lakes in the basin, Yalca is chemically and physically unstable (Dangavs \& Dalla Salda, 1978; Thorton, 1982), with its hydrologic dynamics linked to the rainfall cycle that in turn produces alternate periods of floods and droughts, each of several years duration (Quiros et al., 2002). The water body is located at a private property and has not supported fishing pressure in the last eight years.

The study period was carried out from September 2005 through July 2007 covering summer (December-March), fall (March-June), winter (June-September) and spring (SeptemberDecember) seasons. Environmental measurements and fish samples were taken at 30- to 40-day intervals. The lake's thermal patterns at $40 \mathrm{~cm}$ depth were obtained through hourly watertemperature recordings by an automatic thermo logger. Daily temperature averages were estimated and analyzed in order to investigate annual oscillation. Fish samples were taken in 5 permanent coastal and open-water zones plus 3 alternative sampling sites when depth restricted the use of the gear in the permanent ones (Fig. 1). Different types of fishing gears were employed: e.g., fyke nets (Colautti, 1998), beach seines, a set of 5 gill nets each $25 \mathrm{~m}$ long (stretch mesh sizes: 20, 70, 80, 110, and $130 \mathrm{~mm}$ ), trammel net $25 \mathrm{~m}$ long (60-mm inner mesh and 120 $\mathrm{mm}$ outer mesh) and 30 longline hooks (Mustad 4/0). All gears were set in duplicate at each sampling date. The fishing effort $(12 \mathrm{~h})$ extended from dusk to the following dawn for each type of passive fishing gear.

The fish were weighed (W) at a 1-g precision and their standard length (SL) and total length (TL) recorded at a 1-mm precision; gonads were weighed at a 0.1 -g precision. Scales were extracted from the right side of the body behind the operculum and above the lateral line, then stored in paper envelopes.

The length-frequency distribution was made by grouping the captured fish into $10-\mathrm{mm}$ length intervals. The scales to be analyzed for age determination were selected according to the following criteria: symmetry, regularity of shape, and similarity in size. Five scales per individual were chosen and submerged in an enzyme solution for $48 \mathrm{~h}$; then brushed, rinsed, and fixed between two 1.5-mm-thick slides. Scales were read under a Nikon SMZ 800 stereoscopic microscope with a built-in camera and measurements obtained by means of the Image-Pro Plus software.

Ring identification followed the criteria outlined by Ramírez

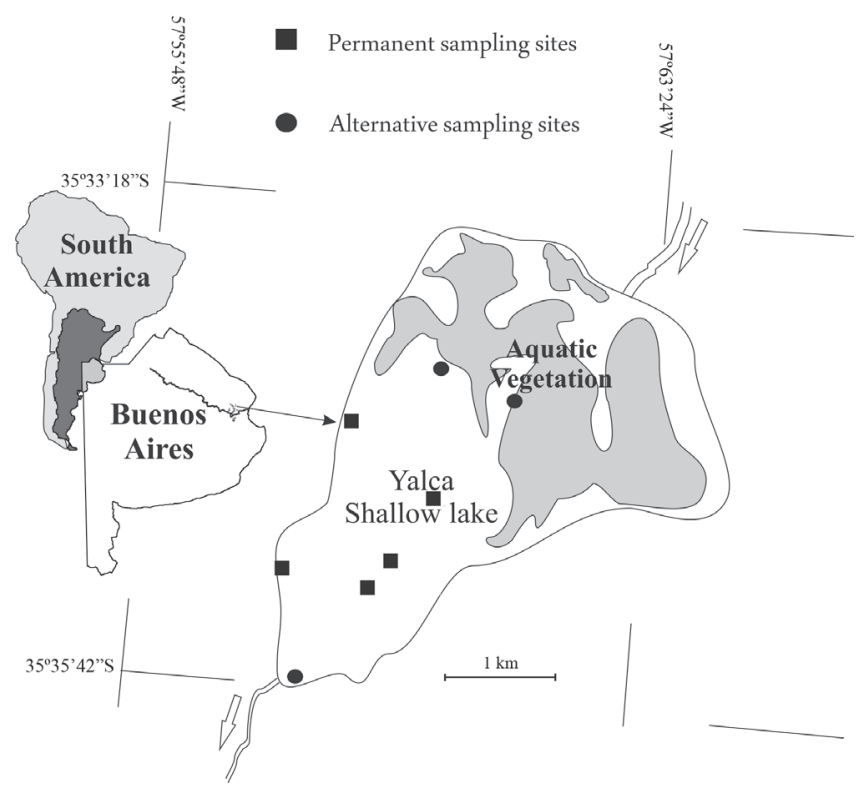

Fig. 1. Geographical location of Yalca Lake and its geographical position in south America. The sampling stations in the lake are indicated. 
(1963). The total radius (TR) was measured from the focus to the most distant point of the anterior scale margin. Each successive growth radius (R1, R2,...Rn) was measured over this axis at a $1-\mu \mathrm{m}$ precision. The $\mathrm{Rn}$ values obtained were grouped at intervals of $0.18 \mathrm{~cm}$. The length of this interval had been obtained by dividing the entire range of $\mathrm{Rn}$ values by 45 . Considering that the species has more than one spawning per reproductive season, we analyzed the R1 frequency distribution in order to verify the existence of multiple annual cohorts and then divided the data base by polymodal decomposition using this criterion, if necessary, grouping fishes with similar $\mathrm{Rn}$ values regardless of its maximum number of rings. The Rn-frequency distribution for pooled data and for the female- and male-subsets were decomposed into their normal components in order to obtain the mean $\mathrm{Rn}$ value for each growth ring and the respective standard deviations (Quinn \& Deriso, 1999). The differences in the mean value between sexes at each Rn were assessed by the Student $t$ test.

The average TR (ATR) was calculated for each individual and a linear model was fitted to the TL-ATR relationship in order to obtain the back-calculation equation for estimating the average fish size at each mean $\mathrm{Rn}$. With the purpose of validating the age estimation, the percentage marginal increment (MI\%) was calculated based on individuals from the best represented group through the following formula:

$$
\mathrm{MI} \%=\left(\mathrm{TR}-\mathrm{Rn}_{\max }\right) \cdot 100 / \mathrm{TR}
$$

where Rnmax is the distance along the radius from the focus to the latest ring.

A third-order Fourier-harmonic model was fitted to the mean MI\%-sampling-period-pair data to obtain a description of the annulus-formation process (Rey-Pastor et al., 1987; Freyre et al., 2009). The mean annulus-formation period was defined as the maximum value of the model's second derivative. Differences among the estimated MI\% values at different periods were assessed by means of the one-way ANOVA.

In order to analyze the relationship between the dynamics of scale marking and the physiologic processes in $H$. aff. malabaricus, we assessed yearly reproductive and condition patterns by considering female gonadosomatic index (GSI) and the relative condition factor $(\mathrm{Kn})$ of the females, after Le Cren (1951), as:

$$
\mathrm{GSI}=\mathrm{W} \dot{\mathrm{g}} \cdot 100 / \mathrm{W}
$$

where $\mathrm{Wg}$ represents the ovary weight and $\mathrm{W}$ the individual's body weight.

$$
\mathrm{Kn}=\mathrm{W} / \mathrm{W}^{\prime}
$$

where $\mathrm{W}^{\prime}$ is the length-specific mean weight for a given fish within the population as predicted by the population weight-length relationship obtained from 244 pair wise data, where $\log \mathrm{W}^{\prime}=0.00005+2.9904 \log \mathrm{Lt}$
With the aim at facilitating the comparisons, the range of variation in Kn was expressed on a scale from 1 to 3 according to the equation:

$$
\mathrm{Kn}_{\exp }=4-\left(\left(\mathrm{Kn}_{\max }-\mathrm{Kn}\right) \cdot 3 /\left(\mathrm{Kn}_{\text {max }}-\mathrm{Kn}_{\text {min }}\right)\right)
$$

where $\mathrm{Kn}_{\text {exp }}=$ the $\mathrm{Kn}$ expanded value, and $\mathrm{Kn}_{\text {max }}$ and $\mathrm{Kn}_{\text {min }}$ are the maximum and minimum mean $\mathrm{Kn}$ values, respectively.

For both GSI and Kn, a Fourier second-order polynomial equation was fitted to the variation in the yearly pattern.

The length-at-age data were fitted by the maximumlikelihood method to the von Bertalanffy growth model (Haddon, 2001) following formula:

$$
\mathrm{L}_{\mathrm{t}}=\mathrm{L}_{\infty} \cdot\left[1-\mathrm{e}^{-\mathrm{k}(\mathrm{t}-\mathrm{t} 0)}\right]
$$

Where:

$\mathrm{L}_{\mathrm{t}}=$ total length or standard length of a fish at the moment $\mathrm{t}$, $\mathrm{t}=$ time in years,

$\mathrm{L}_{\mathrm{oo}}=$ total or standard asymptotic length,

$\mathrm{k}=$ growth coefficient,

$\mathrm{t}_{0}=$ hypothetical time at zero length.

To compare the growth among Yalca and other shallow lakes within the pampean region and/or in other SouthAmerican river basins, the published data for lengths at a given age were transformed to total lengths, when necessary, and the von Bertalanffy curve fitted. Those conversions were made by means of a linear equation obtained from SL and TL pair wise data from trahiras $(\mathrm{N}=680)$ captured in several pampean shallow lakes according to the following equations:

$$
\begin{aligned}
& \mathrm{SL}=0.893 . \mathrm{TL}-6.950 \quad \mathrm{TL}=1.152 . \mathrm{SL}+10.173 \\
& \mathrm{r}^{2}=0.99
\end{aligned}
$$

Then the growth performance index ( $\left.\varnothing^{\prime}\right)$ was calculated based on the following formula (Pauly \& Munro, 1984):

$$
\varnothing^{\prime}=\log (\mathrm{K})+2 \log \left(\mathrm{L}_{\mathrm{oo}}\right)
$$

\section{Results}

Temperature patterns were closely monitored throughout the year and showed a clear seasonal variation and wide amplitude (Fig. 2a). The annual frequency distribution of daily water temperatures was bimodal, thus suggesting the existence of two thermal states over the annual cycle (Fig. 2b).

A total of 562 trahiras were collected during the entire sampling period. The trahira-size distribution ranged between 255 and $616 \mathrm{~mm}$, with individuals between 330 and $400 \mathrm{~mm}$ (TL) being highly represented (Fig. 3).

The decomposition of polymodal distribution allowed recognition of a first ring with a bimodal distribution (Fig. 4a), thus justifying a division of the data set into two groups. As 

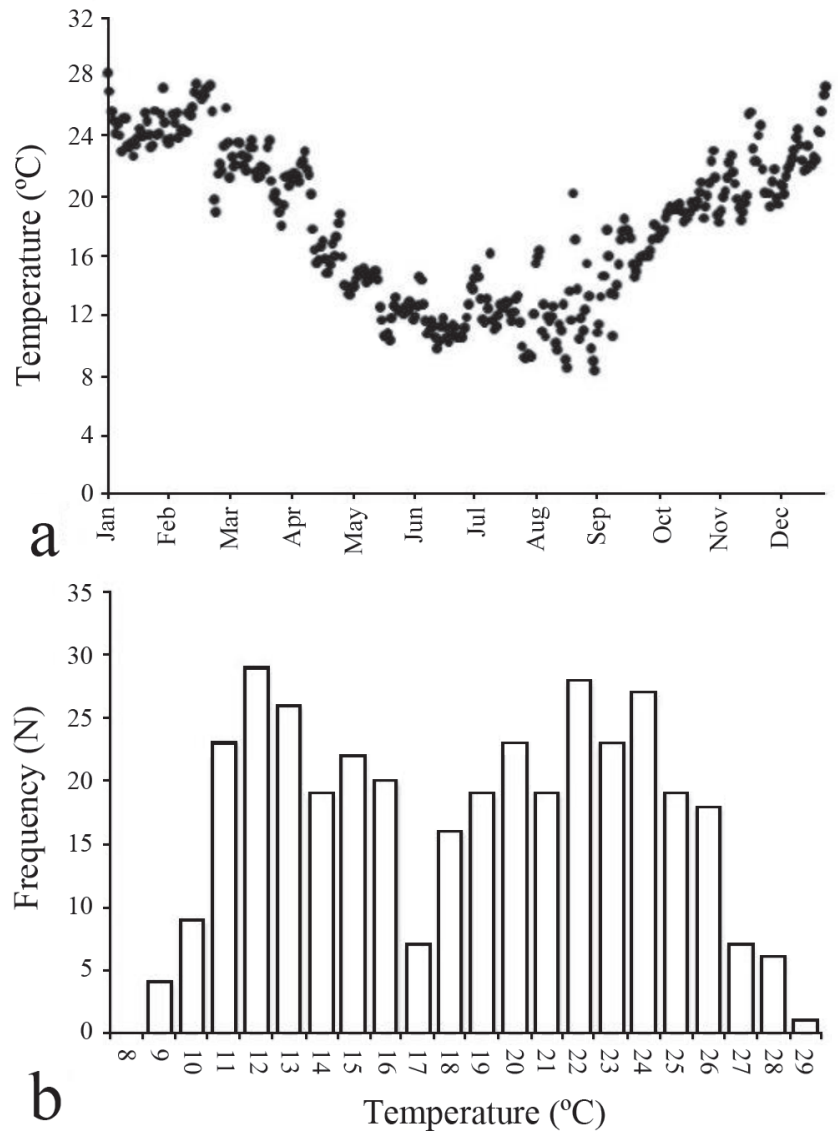

Fig. 2. Average daily water temperatures registered at Yalca Lake during an annual cycle (a), and frequency distribution of the average daily temperatures (b).

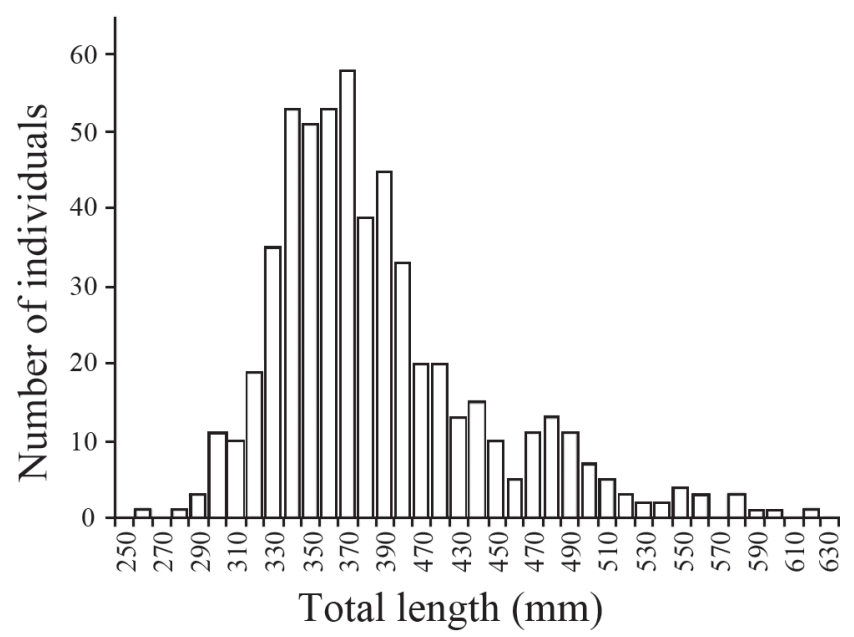

Fig. 3. Frequency distribution of total lengths of the trahira Hoplias aff. malabaricus captured during the entire sampling period.

a result, we obtained one group containing fish with first rings closer to the scale nucleus (summer group; Fig. 4b) and another group containing fish with first rings far away from the scale nucleus (spring group; Fig. 4c). All told, we were able to detect up to four normal components in cohort 1 and
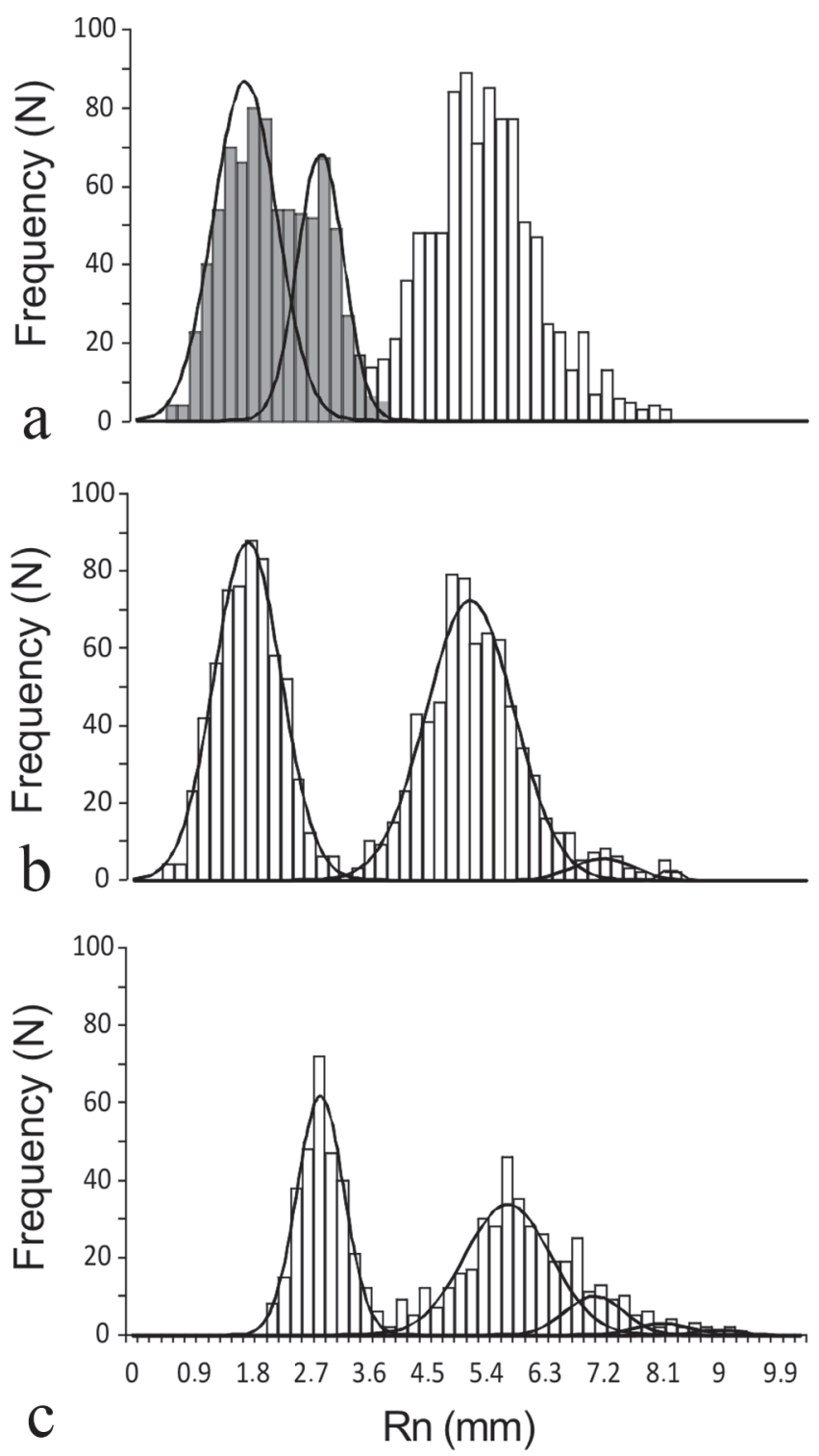

Fig. 4. Total frequency distribution of the scale radius (Rn) and decomposition of first ring measurements (shaded columns) in order to discriminate between the fish from summer and from spring groups (a). Decomposition of polymodal frequency distribution of ring measures from summer group (b) and spring group (c).

five in cohort 2 . The maximum number of decomposed normal curves matched the maximum number of growth marks observed in the scales from each group.

Neither of the groups showed significant differences between the female and male Rn comparisons ( $p>0.05$ ), thus indicating that both sexes have similar growths and enabling a pooling of the data.

The mean value and standard deviation of each normal curve were transformed to TL values by means of the following linear model fitted by least squares to TL-ATR pair wise data:

$$
\begin{array}{lll}
\mathrm{TL}=54.014 \cdot \mathrm{ATR}+47.12 & \mathrm{r}^{2}=0.7439 \\
\mathrm{p}<0.001 \quad \mathrm{~N}=190 &
\end{array}
$$


The respective back-calculated lengths from this equation are shown in Table 1. Most of the individuals had scales with up to 2 rings, indicating a narrow age structure that likely reflected high mortality rates after the second year of life. For trahiras of three or more years of age, no differences were noted for the length-at-age structures between groups.

Marginal-increment analysis indicated a defined seasonalgrowth pattern characterized by a rapid increment in scale radius during the summer season that peaked at the end of that period. In contrast, the growth decreased during the fall, reaching the lowest incremental value, as estimated by the second derivative, at the start of June. This analysis further identified that the initial ring formation is followed by an essentially negligible increment between June and December (Fig. 5). Likewise, the lowest GSI values were recorded during the winter, but then increased from September on up to a peak in January, when the species reproduced. This trend was paralleled by the $\mathrm{Kn}$ variation, which increased probably as consequence of gonad development. As would be expected, after spawning the GSI and Kn values decreased, while the marginal growth subsequently increased between January and March.

The fitted von Bertalanffy-curve parameters indicated that the summer group exhibited a faster growth rate and had shorter asymptotic lengths than the spring group (Table 2). Those differences indicated that the maximum growth rate for the summer group took place during the first two years of life, whereas with the spring group the growth rate decreased only after the third year.

A comparison of these von Bertalanffy curves with those obtained by other authors in four pampean shallow lakes (Monte, Lobos, Chascomús, and Indio Muerto) and with those from Cienaga Grande de Lorica (Colombia); Amanari Maranguape Dam, State of Ceará (Brazil); and Monjolinho Dam, São Paulo (Brazil), illustrated certain significant differences (Table 2, Fig. 6). The Yalca-shallow-lake growth curve was close to those obtained for the Chascomús and Indio-Muerto populations, but differed from those fitted for Monte and Lobos. The greatest divergence, however, was observed with the populations located outside the pampean

Table 1. Back-calculated mean total length (TL) and standard length (SL) at time of scale-ring formation and the respective standard deviations (SD) for each trahira group.

\begin{tabular}{|c|c|c|c|c|}
\hline \multicolumn{5}{|c|}{ Summer group } \\
\hline Age(Years) & Mean TL (mm) & $\mathrm{SD}(\mathrm{mm})$ & Mean SL $(\mathrm{mm})$ & $\mathrm{SD}(\mathrm{mm})$ \\
\hline$\overline{1}$ & 141.10 & 74.66 & 112.16 & 54.01 \\
\hline 2 & 324.52 & 83.31 & 272.68 & 61.58 \\
\hline 3 & 433.83 & 71.97 & 368.35 & 51.66 \\
\hline 4 & 489.7 & 54.03 & 417.30 & 35.96 \\
\hline \multicolumn{5}{|c|}{ Spring group } \\
\hline$\overline{1}$ & 203.47 & 66.49 & 166.75 & 46.86 \\
\hline 2 & 358.74 & 82.86 & 302.63 & 61.19 \\
\hline 3 & 430.50 & 71.18 & 365.43 & 50.97 \\
\hline 4 & 486.50 & 69.88 & 414.44 & 49.83 \\
\hline 5 & 533.21 & 67.59 & 455.32 & 47.82 \\
\hline
\end{tabular}

region and at lower latitudes, where those trahira attained smaller asymptotic (maximum) sizes.

\section{Discussion}

The trahira population-age structure at Yalca shallow lake exhibited a low frequency of individuals older than three years of age, despite the use of a sampling design that employed a set of different fishing methods so as to cover the whole water body and thus sample the entire population. This characteristic age structure is nevertheless in agreement with previous analyses performed at other pampean lakes (Ramirez, 1963; Grosman et al., 2004).

We were able to identify two cohorts per year, which distribution provided a reproductive period that lasted up to three months with several spawning pulses, as is shown in Fig. 5, where female GSI values are highly variable from November to January. This particular reproductive pattern of trahira has been reported by earlier studies (Paiva, 1974; Marques et al., 2001; Bialetzki et al., 2002; Rosso, 2007). The presence of those cohorts was validated by the agreement between the maximum number of observed rings and the number of unimodal components in the ring-frequency distribution.
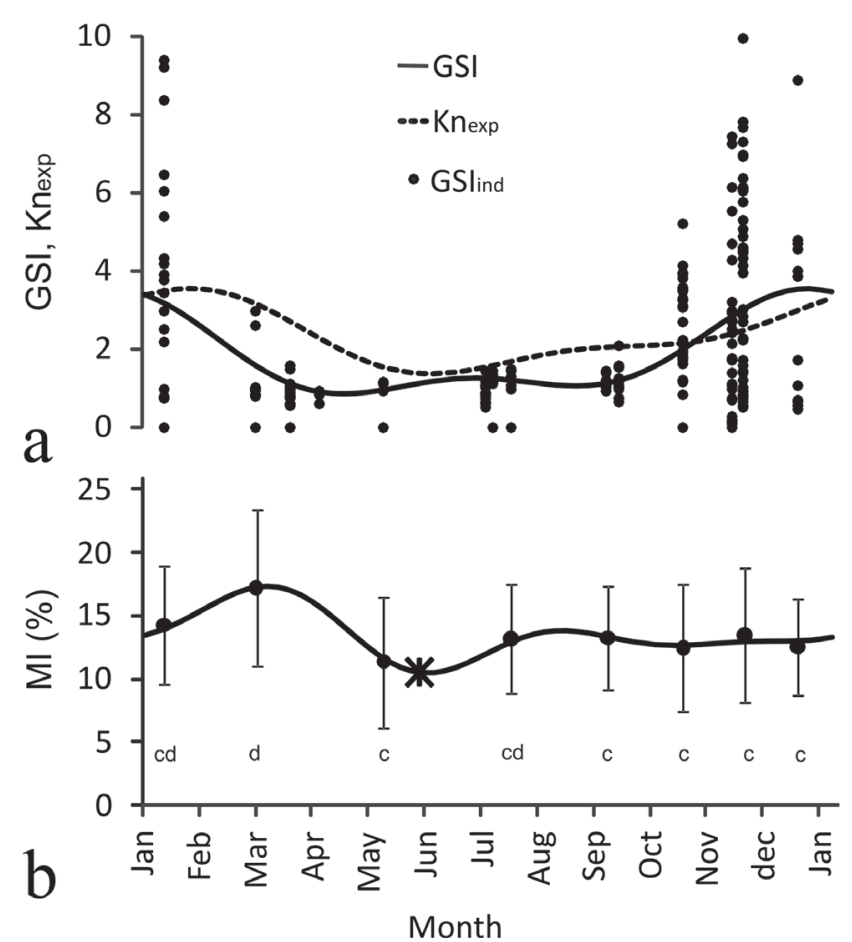

Fig. 5. Trahira annual variation of observed individual Gonadosomatic index (GSI) and its respective fitted model, and expanded condition index (Knexp) curve (a). Mean relative marginal-increment scale index (MI\%) and its respective standard deviations at each sampling date with the corresponding fitted model. Asterisk in MI (\%) curve indicates the mean date of ring formation. Different letters below the $\mathrm{MI} \%$ mean values indicate significant differences $(\mathrm{p}<0.05)(\mathbf{b})$. 
Table 2. Parameters of the von Bertalanffy equation estimated for Yalca shallow lake and for different trahira populations. $\mathrm{LT}_{\mathrm{o}}$ : asymptotic total length; $\mathrm{K}$; growth rate; $\mathrm{t}_{0}$ : theoretical age at zero length; phi: growth performance index.

\begin{tabular}{lccccc}
\hline Environment & $\mathrm{LT}_{\mathrm{oo}}(\mathrm{mm})$ & $\mathrm{K}$ & $\mathrm{t}_{0}$ & $\mathrm{phi}$ & Source \\
\hline Yalca, summer group & 486.54 & 0.57 & 0.54 & 5.1 & This study \\
Yalca, spring group & 499.69 & 0.47 & 0.13 & 5.1 & This study \\
Chascomús & 536.75 & 0.37 & 0.02 & 5 & Ramirez, 1963 \\
Indio Muerto & 564.38 & 0.51 & 0.03 & 5.2 & Grosman et al., 2004 \\
Monte & 817.59 & 0.08 & -0.76 & 4.7 & Domanico, 1998 \\
Lobos & 792.06 & 0.07 & -1.02 & 4.6 & Domanico et al., 1993 \\
Cien aga Gran de de Lorica & 481.00 & 0.29 & -0.50 & 4.8 & Tordecilla-Petro et al., 2005 \\
Amanari, Maranguape & 388.01 & 0.26 & -1.29 & 4.6 & Paiva, 1974 \\
Reservoir, femal es & & & & & Paiva, 1974 \\
Amanari, Maranguape & 452.34 & 0.19 & -1.68 & 4.6 & Barbieri 1989 \\
Reservoir, males & 405.00 & 0.24 & 0.10 & 4.6 &
\end{tabular}

In Yalca shallow lake trahira growth exhibited a well defined seasonal pattern, where maximum rates took place during the warm months and almost no growth was observed when temperature dropped below $15^{\circ} \mathrm{C}$. This feature has a notable effect during the first year of life because the growth period of the spring group can extend for up to 6 months, whereas that of the summer group lasted for only 3 months before the temperature started decreasing in the fall. As shown by marginal-growth analysis and the growth rate $(\mathrm{k})$ derived from the von Bertalanffy curve, a fast growth was observed for the summer group; with the spring group evidencing a slower rate, though accompanied by a more extensive growth period. These results diverged from those reported by Dománico et al. (1993) and Dománico (1998) for the Lobos and Monte shallow-lake populations, where their analyses were made assuming the existence of only a single yearly cohort.

When the population growth at Yalca shallow lake was compared with the corresponding data from lakes located at lower latitudes, such as in Colombia $\left(9^{\circ} 14^{\prime} \mathrm{N}\right)$ and Brazil $\left(3^{\circ} 54^{\prime} \mathrm{S} 22^{\circ} 00^{\prime} \mathrm{S}\right)$, clear differences emerged in the growth parameters, probably due to differences in the thermal regime. According to Petry et al. (2007), the optimal temperature for growth in mass of $H$. aff. malabaricus is $21.4^{\circ} \mathrm{C}$; whereas the maximum prey-consumption temperature is $30^{\circ} \mathrm{C}$ and ceases at some level between 18 and $14^{\circ} \mathrm{C}$. The shallow lakes of the lower Salado River basin are exposed to seasonal thermal variations where the temperature ranges between $16^{\circ} \mathrm{C}$ and $26^{\circ} \mathrm{C}$ for about 220 days in a given year and drops below $16^{\circ} \mathrm{C}$ for the rest of the year. This thermal structure represents a notable difference from that of tropical waters, where the species live exposed to $28^{\circ} \mathrm{C}$ almost constantly (Paiva, 1974; Tordecilla-Petro et al., 2005). Climatic effects also define consequential differences in the metabolic functioning of trahira among temperate, subtropical, and tropical regions. Thus, in the lower Salado-River basin, the thermal seasonality is such that the temperatures oscillate $\pm 5^{\circ} \mathrm{C}$ around the optimal growth temperature for some $60 \%$ of the year. During the remaining days, the low temperatures may induce "hibernation" (Ramirez, 1964; Ringuelet et al., 1967) and a consequent reduction in metabolic costs.

The seasonal growth of the species was corroborated by an analysis of biological indices, which data demonstrated a differential energy allocation depending on the time of year (Balboni et al., 2009). Certainly during the coldest season, when temperatures fall below $14^{\circ} \mathrm{C}$, metabolism must necessarily decrease and prey consumption would be nil. That circumstance, however, is not critical for this species because these fish are adapted to withstand starvation periods of more than 90 days (Petry et al., 2007). Nevertheless, in certain dry winters (with low water levels) temperatures can fall and remain below $5^{\circ} \mathrm{C}$ for several days, thus promoting massive mortalities (Freyre, 1967; Gomez, 1996; Colautti et al., 1998). Those conditions at higher latitudes may furthermore create an even greater overwinter mortality with pronounced effects on the population age structure that, in turn, would need to be compensated for by larger body sizes and faster growth rates. This kind of population response (countergradient effect) has been found

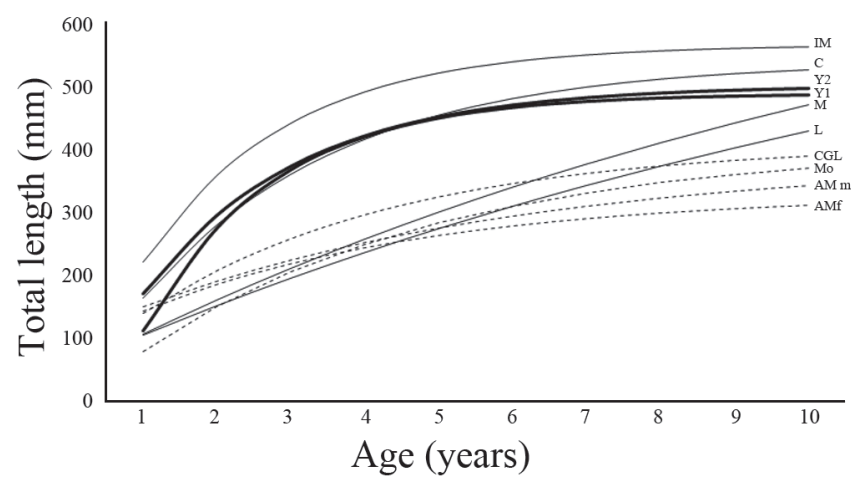

Fig. 6. Von Bertalanffy growth curves of trahira Hoplias aff. malabaricus obtained by several studies in South America (see Table 2 for sources information): Yalca summer group 1, Y1; Yalca spring group, Y2; Chascomús, C; Indio Muerto, IM; Monte, M; Lobos, L; Cienaga Grande de Lorica, CGL; Amanari Maranguepe female, AM f; Amanari Maranguepe male, AM m. 
in other fish species (Conover, 1990; Conover \& Present, 1990; Power \& McKinley, 1997).

At lower latitudes where temperature stays over the maximum value for food conversion by the species all the time, thus generating high metabolic rates and more continuous prey consumption, the reproductive season appears to extend from October to June (Barbieri, 1989; Marques et al., 2001) and is influenced by temperature and precipitation (Marques et al., 2001). In pampean lakes, spawning occurs only in the late spring and early summer, at the start of the favorable season for the species. This strategy of delaying and shortening the reproductive period could be linked to maximization of growth during the part of the year when environmental conditions are better for trahira. That pattern could be considered as an adaptive physiologic and demographic response to cope with broad thermal variation and hydrologic instabilities such as those observed in pampean lakes. Such adaptations may be supported by a particularly evolutionary life history adapted to this geographic area resulting in genetic diversity divergences with other populations (Blanco et al., 2010). In this sense, it is important consider also that $H$. aff. malabaricus may be a group of different species, therefore dissimilarities in behavioral and biological processes among regions could be explained in part by possible taxonomical differences.

If we consider the trahira's reproductive season in shallow pampean lakes and recognize that occasional winter mortality could reduce the reproductive stock so as to promote weak annual cohorts, such considerations would explain why pampean populations show truncated size structures with very low numbers of sizeable adults. Nevertheless, other conditions such as predator-prey relationships, food availability, and fishing practices may also act as controlling forces to regulate the trahira population structure and density in those lakes. The combined action of these influences can therefore shape age structure, thus producing unbalanced populations as was found at the Yalca and other shallow pampean lakes such as Chascomús and Indio Muerto where trahira populations have been studied (Ramirez, 1963; Grosman et al., 2004).

Future efforts should be directed at gathering more sound information based on annual growth, variability in the mechanisms of recruitment, and mortality along with the relationship of these parameters to environmental variables in order to promote a more comprehensive knowledge of population structure and dynamics in pampean shallow lakes.

\section{Acknowledgements}

We are in debt to Leonardo Hubscher for facilitating the entrance to Yalca shallow lake and providing with logistic support during sampling program. The authors are grateful to Donald F. Haggerty for editing the final version of the manuscript.

\section{Literature Cited}

Balboni, L., D. C. Colautti \& C. R. M. Baigún. 2009. Cambios en los índices biológicos de la tararira, Hoplias malabaricus, (Bloch, 1794) en un ciclo anual en la laguna Yalca, Provincia de Buenos Aires, Argentina. Biología Acuática, 26: 7-17.

Barbieri, G. 1989. Dinâmica da reprodução e crescimento de Hoplias malabaricus (Bloch, 1794) (Osteichthyes: Erythrinidae) da represa do Monjolinho, Sao Carlos/SP. Revista Brasileira de Zoologia, 6: 225-233.

Barla, J., M. S. Vera \& E. D. O. Brien. 2003. Relative abundance and autecology of three piscivorous fishes in lakes of the upper basin of Salado River (Buenos Aires Province, Argentina). Ecología Austral, 13: 205-214.

Bialetski, A., K. Nakatani, P. V. Sanchez \& G. Baumgartner. 2002. Spatial and temporal distribution of larvae and juveniles of Hoplias malabaricus (Characiformes, Erythrinidae) in the Upper Paraná River Floodplain, Brazil. Brazilian Journal of Biology, 62: 211-222.

Blanco, D. R., R. L. Lui, L. A. C. Bertollo, V. P. Margarido \& O. Moreira-Filho. 2010. Karyotype diversity between allopatric populations of the group Hoplias malabaricus (Characiformes, Erythrinidae): evolutionary and biogeographic considerations. Neotropical Ichthyology, 8: 361-368.

Colautti, D. 1998. Sobre la utilización de trampas para peces en las lagunas pampásicas. Revista de Ictiologia, 6: 17-23.

Colautti, D., M. Remes Lenicov, N. Gómez \& M. Claps. 1998. Mortandad de peces en el arroyo San Miguel (Partido de Pila, Provincia de Buenos Aires). Gayana Zoologica, 62: 191-197.

Conover, D. O. 1990. The relation between capacity for growth and length of growing season: evidence for and implications of countergradient variation. Transactions of the American Fisheries Society, 119: 416-430.

Dangavs, N. V. \& L. H. Dalla Salda. 1978. Geología sedimentología y limnología de la laguna Yalca. Revista de la Comision de Investtigaciones Científicas, Provincia de Buenos Aires, La Plata, 67p.

Dománico, A. 1998. Edad y crecimiento de Hoplias malabaricus malabaricus (Bloch, 1794) (Teleostei, Erythrinidae) en la laguna de San Miguel del Monte (Argentina) y comparación con otros ambientes lenticos pampásicos. Museo Argentino de Ciencias Naturales Bernardino Rivadavia. Hidrobiología, 8(4): 31-41.

Dománico, A., R. Delfino \& L. Freyre. 1993. Edad y crecimiento de Hoplias malabaricus (Bloch, 1794) (Teleostei, Erythrinidae) en la laguna de Lobos. Iheringia, Série Zoología, 74: 141-149.

Frenguelli, J. 1956. Rasgos generales de la hidrografía de la Provincia de Buenos Aires. Boletín del Ministerio de Obras Públicas Laboratorio de Ensayo de Materiales e Investigaciones Tecnológicas, 2(62): 1-21.

Freyre, L. 1967. Consecuencias de la mortandad de peces por las temperaturas extremas de Junio de 1967 en Laguna Chascomús. Agro, 9: 35-46.

Freyre, L., D. C. Colautti, M. E. Maroñas, E. D. Sendra \& M. Remes Lenicov. 2009. Seasonal changes in the somatic indices of the freshwather silverside, Odontesthes bonariensis (Teleostei, Atheriniformes) from a Neotropical shallow lake (Argentina). Brazilian Journal of Biology, 69: 389-395.

Galarowics, T. L. \& D. H. Wahl. 2003. Difference in growth, metabolism, consumption and metabolism among walleys from different latitudes. Transactions of the American Fisheries Society, 132: 425-437. 
Gomez, S. E. 1996. Resistenza alla temperatura e alla salinitá in pesci della Provincia di Buenos Aires (Argentina), con implicazione zoogeografiche Pp. 171-192. In: $4^{\circ}$ Convengo Nazionale. Trento Italia. Distribuzione della fauna ittica italiana. Ati congresali 12-13 dicembre 1991.

Grosman, F., V. Birnstil, J. Cabral, L. March, C. Merlos, G. Rudzik \& L. Vavrin. 2004. ¿El uso actual justifica acciones de gestión en la tararira Hoplias malabaricus? Una visión desde los aspectos socioeconómicos y biológicos. Congreso Iberoamericano Virtual de Acuicultura, 362-374p. http://www.revistaaquatic.com/ civa2004/. Date of Access: 15 de Noviembre de 2006.

Haddon, M. 2001. Modelling and quantitative methods in fisheries. Chapman \& Hall/CRC, 406p.

Le Cren, E. D. 1951. The length weight relationship and seasonal cycle in gonad weight and condition in the perch Perca fluviatilis. Journal of Animal Ecology, 20: 201-219.

López, H. L., C. R. Menni \& L. C. Protogino. 1994. Bibliografía de los peces de agua dulce de Argentina. Suplemento 1993. En: Situación ambiental Provincia de Buenos Aires. A. Recursos y rasgos naturales en la evaluación ambiental, 4: 1-29.

López, H., C. R. M. Baigún, J. Iwaszkiw, R. Delfino \& O. Padín. 2001. La cuenca del Salado: Uso y posibilidades de sus recursos pesqueros. Universidad de La Plata, La Plata, 75p.

López, H. L., R. C. Menni, M. Donato \& A. M. Miquelarena. 2008. Biogeographical revision of Argentina (Andean and Neotropical Regions): an analysis using freshwater fishes. Journal of Biogeography, 35: 1563-1579.

Marques, D. K., H. de C. B. Gurgel \& I. de Lucena. 2001. Época de reprodução de Hoplias malabaricus Bloch, 1794 (Osteichthyes, Erythrinidae) da barragem do rio Gramame, Alhandra, Paraíba, Brasil. Revista Brasileria de Zoociências Juiz de Fora, 3: 61-67.

Menni, R. C. 2004. Peces y ambientes en la Argentina continental. Monografías del Museo Argentino de Ciencias Naturales, La Plata, 5: 316.

Modde, T. \& C. G. Scalet. 1985. Latitudinal growth effects on predator-prey interactions between largemouth bass and bluegills in ponds. North American Journal of Fisheries Management, 5: 227-232.

Moraes, M. F. P. G. \& I. F. Barbola. 1995. Hábito alimentar e morfología do tubo digestivo de Hoplias malabaricus (Osteichthyes, Erythrinidae), in Lagoa Dourada, Ponta Grossa, Paraná, Brasil. Acta Biologica Paranaense Curitiba, 24: 1-23.

Oyakawa, O. T. 2003. Family Erythrinidae (Trahiras). Pp 238240. In: Reis, R. E., S. O. Kullander \& C. J. Ferraris Jr. (Eds.). Checklist of the freshwater fishes of South and Central America. Porto Alegre, Edipucrs, 729p.

Paiva, P. M. 1972. Fisioecología da traira, Hoplias malabaricus (Bloch), no nordeste brasileiro. Crescimento, resistência a salinidade, alimentação y reprodução. Unpublished Ph.D. Dissertation, Instituto de Biociências de Universidade de São Paulo. 140 p.

Paiva, P. M. 1974. Crescimento, alimentação e reprodução da traíra Hopias malabaricus no nordeste brasileiro. São Paulo, Centro de Ciências Agrárias. Universidade Federal do Ceará, 32p.

Pauly, D. \& J. Munro. 1984. Once more on the comparison of growth in fish and invertebrates. Fishbyte, 2(1): 21.
Petry, A. C., A. A. Agostinho, P. A. Piana \& L. C. Gomes. 2007. Effects of temperature on prey consumption and growth in mass of juvenile trahira Hoplias aff. malabaricus (Bloch,1794). Journal of Fish Biology, 70: 1855-1864.

Petry, A. C., L. C. Gomes, P. A. Piana \& A. A. Agostinho. 2010. The role of the predatory trahira (Pisces: Erythrinidae) in structuring fish assemblages in lakes of a Neotropical floodplain. Hydrobiologia, 651: 115-126.

Philipp, D. P. 1992. Stocking Florida largemouth bass outside its native range. Transactions of the American Fisheries Society, 121: 686-691.

Power, M. \& R. S. McKinley. 1997. Latitudinal variation in lake Sturgeon size as related to the thermal opportunity for growth. Transactions of the American Fisheries Society, 126: 549-558.

Quinn, T. J. II. \& R. B. Deriso. 1999. Quantitative fishery dynamics. Oxford, New York, 566p.

Quist, M. C., C. S. Guy, R. D. Schulys \& J. M. Stephen. 2003. Latitudinal comparisons of Walleye growth in North America and factors influencing growth of Walleyes in Kansas reservoirs. North American Journal of Fisheries Management, 23: 677-692.

Quirós, R., A. Rennella, M. Boveri, J. J. Rosso \& A. Sosnovsky. 2002. Factores que afectan la estructura y el funcionamiento de las lagunas pampeanas. Ecología Austral, 12: 175-185.

Ramírez, F. 1963. Contribución al conocimiento de la tararira de la laguna de Chascomús. Notas de la Facultad de Ciencias Naturales y Museo de La Plata, La Plata, XX(201): 141-158.

Rey-Pastor J., P. Pi-Calleja, C. A. Trejo. 1987. Análisis matemático. Tomo 3: Análisis funcional y aplicaciones. Buenos Aires: Ed. Kapelusz.

Ringuelet, R. A., R. H. Aramburu \& A. Alonso de Aramburu. 1967. Los peces argentinos de agua dulce. Comisión de Investigaciones Científicas, Buenos Aires, 602p.

Rios, F. S., Kalinin, A. L. \& F. T. Rantin. 2002. The effects of longterm food deprivation on respiration and haematology of the neotropical fish Hoplias malabaricus. Journal of Fish Biology 61: 85-95.

Rosso, J. J. 2007. Peces pampeanos: guía y ecología. L.O.L.A. Literature of Latin America. Buenos Aires, 224p.

Saad, A. M., A. C. Beaumord \& E. P. Caramaschi. 2002. Effects of artificial canal opening on fish structure community of Imboassica Coastal Lagoon, Rio de Janeiro, Brazil. Journal of Coastal Research, 36: 634-639.

Tordecilla-Petro, G., S. Sánchez-Banda \& C.Olaya-Nieto. 2005. Crecimiento y mortalidad del moncholo (Hoplias malabaricus) en la ciénaga Grande de Lorica, Colombia. MVZ-Cordoba, 10: 623-636.

Thorton, R., M. V. Dangavs, D. Freggiaro, A. Strelsik, C. Garcia \& L. Freyre. 1982. Los ambientes lagunares de la provincia de Buenos Aires. Documento relativo a su conocimiento y manejo. $1^{\circ}$ Ed. La Habana: Comisión de Investigaciones Científicas, La Plata, 55p.

Accepted February 3, 2011 Published June 30, 2011 